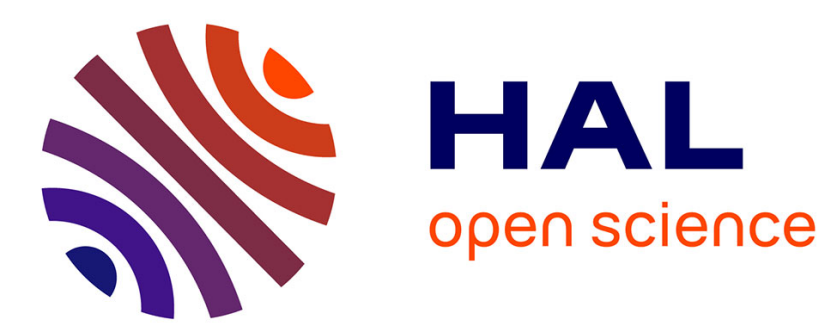

\title{
THE CHEMICAL REVOLUTION AND PHARMACY: A DISCIPLINARY PERSPECTIVE
}

\author{
Jonathan Simon
}

\section{To cite this version:}

Jonathan Simon. THE CHEMICAL REVOLUTION AND PHARMACY: A DISCIPLINARY PERSPECTIVE. Ambix, 1998, 10.1179/amb.1998.45.1.1 . hal-01867749

\section{HAL Id: hal-01867749 \\ https://hal.univ-lorraine.fr/hal-01867749}

Submitted on 4 Sep 2018

HAL is a multi-disciplinary open access archive for the deposit and dissemination of scientific research documents, whether they are published or not. The documents may come from teaching and research institutions in France or abroad, or from public or private research centers.
L'archive ouverte pluridisciplinaire HAL, est destinée au dépôt et à la diffusion de documents scientifiques de niveau recherche, publiés ou non, émanant des établissements d'enseignement et de recherche français ou étrangers, des laboratoires publics ou privés. 


\section{THE CHEMICAL REVOLUTION AND PHARMACY: A DISCIPLINARY PERSPECTIVE.}

By Jonathan Simon, Université de Lorraine. This article was published in Ambix, March 1998 Vol. 45, no. 1: pp. 1-13.

\section{INTRODUCTION.}

What was the chemical revolution? This question lies at the heart of the historiography of eighteenth-century chemistry and animates the present paper. The orthodox response has placed Lavoisier at the center of an intellectual transformation, characterising him as both the author of the revolution and the founder of modern chemistry. For those who want to focus the credit on Lavoisier, the chemical revolution consists in his supplanting Stahl's phlogiston theory with the substantially correct oxygenic view of combustion. With this 'paradigm shift', the story goes, Lavoisier took a vital step forward in the development of modern chemical theory. The twin advantages of this view of the chemical revolution are philosophical and pedagogical, or, in other words, such a revolution is both easily thought and easily taught. Indeed, the most widely disseminated version of this intellectual revolution is that found in Thomas Kuhn's The Structure of Scientific Revolutions, a philosophical treatise written by a historian of science. Furthermore, Kuhn learned this version of the chemical revolution from James Bryant Conant whose most fully developed presentation on the subject was intended specifically to educate humanities students in the sciences. ${ }^{1}$

Here, I want to approach the question from a disciplinary perspective, focussing on the relationship between chemistry and pharmacy in order to see what new insights this might provide concerning the nature of the chemical revolution. Although many pharmacists feature prominently in the history of chemistry, pharmacy itself occupies at best a marginal position in this discipline and as a corollary has an even less significant presence in general histories of science. From the point of view of a twentieth-century scientist, this might seem natural; after all, the history of chemistry should be about chemistry, and pharmacy is not chemistry. Although I do not intend to argue the case fully here, I believe that this way of 
thinking, which conceives of chemistry and pharmacy as distinct disciplines, was first clearly formulated in the eighteenth century and only became pervasive during the nineteenth. ${ }^{2}$ Instead, what I do want to argue here is that the rejection of chemistry's former associations, if not identity, with pharmacy forms an important feature of the new chemistry developed by Lavoisier and his disciples. Moreover, I contend that this disciplinary perspective should be integrated into our view of the chemical revolution, thereby moving historians of chemistry beyond the restrictive confines of disembodied intellectual history. ${ }^{3}$

Overall, I would argue that it makes more sense to conceive of the chemical revolution as a multi-facetted transformative process rather than as a single intellectual event. ${ }^{4}$ First, such a view allows us to begin to comprehend the origins of the immensely successful nineteenth-century chemistry, a science built on an expanding institutional base and a growing self-assurance in its ability to intervene usefully in the various chemical arts and industries. Furthermore, the social and institutional dimensions encompassed by this approach should facilitate the historian's task of situating a changing population of chemists as they took advantage of the new disciplinary opportunities that developed in France at the end of the eighteenth century. Therefore, in exploring the growth of chemistry as an independent discipline, it is important to take into account not only the evidence of reconceptualization displayed in the contemporary texts but also the more substantial institutional context that affected the working lives of the various groups of chemists, an area too often neglected in the history of science. In this paper, I will be concentrating my analysis on the textual tradition that charts the disciplinary split between chemistry and pharmacy, but this should not be taken as a measure of its importance compared to the dramatic institutional developments in French chemistry at the end of the eighteenth century.

\section{SEVENTEENTH-CENTURY FRENCH CHEMISTRY.}

If we concentrate solely on chemistry texts written in France towards the end of the eighteenth century, the intimacy of the relationship between pharmacy and chemistry is not particularly striking. Pharmacy, when mentioned at all, is usually given a marginal position in the texts, and is fully subjugated to philosophical chemistry conceived of as an 
independent, albeit practical science. Nowhere is this clearer than in the works of Lavoisier himself, which I will discuss more fully in what follows. If we turn back to French chemistry in the seventeenth century, however, we find a science whose dominant purpose was the preparation of medicaments. At this time, chemistry was considered an inseparable part of pharmacy. Moreover, France produced a distinguished series of chemistry textbooks, whose authors built on one another's work to establish a major European scientific tradition. Their names are well known to historians of chemistry: Lefebvre (1615-1669), Glaser, and probably the best-known, Nicolas Lemery (1645-1715). All these men wrote treatises on chemistry, but it is enough to look through these works to see that their principal goal was to instruct pharmacists in how to prepare the medicaments that were needed to fill the physicians' prescriptions. The texts were written summaries of courses that the authors offered in person, serving to supplement the deficiencies of a pharmacist's education as an apprentice, or simply to refresh his memory.

Lemery first published his Cours de chymie (Course of Chymistry) in 1675, and, according to Fontenelle, it 'sold like a Work of Gallantry or Satire. The Editions followed each other almost yearly, without counting the great number of counterfeit Editions, honorable \& pernicious for the Author'. ${ }^{5}$ Prior to Macquer's publications in the middle of the eighteenth century, Lemery's remained the French textbook in chemistry. What has earned Lemery a particular place in the history of chemistry, however, is his application of corpuscular theory, as he explicitly introduced the mechanistic explanations of Descartes and Gassendi into the realm of chemistry. Too often historians dwell on this aspect of Lemery's work and give the impression of a theoretical chemist producing a corpus similar to that of Robert Boyle. The Course of Chymistry was not, however, a text that dealt primarily in what we could interpret as the theory of chemistry. Lemery's celebrated corpuscular speculations played a secondary role to the practical preparations that provided useful medicines. The full title of the work; A Chemistry Course containing the way in which to perform the operations that are in use in Medicine, by means of an easy method, with the reasoning about each operation, for the instruction of those who want to apply themselves to this science, shows that Lemery had made no attempt to disguise the fact that the work was firmly in the 
pharmaceutical tradition. ${ }^{6}$ The principal aim of the course is manifest in the text as well as the title; it was to give the reader information on how to prepare certain 'mixts' - mineral, vegetable and animal - and how to use them in the treatment of illnesses. The preparation of the red precipitate of mercury is quite typical of the book's contents.

\section{Red precipitate}

Take eight ounces of Mercury revived out of Cinnabar, dissolve it in a sufficient quantity of Spirit of Niter, which is nine or ten ounces; pour the dissolution into a viol or Matrass with a short Neck, set it on Sand, and evaporate all the moisture over a gentle heat, until there remains a white Mass; then drive the fire by little and little to the third Degree, and keep it in this condition till all your matter is turned Red, then take it off the fire, let the Viol cool, and break it to get your Precipitate, which weighs nine ounces. ${ }^{7}$

Although the technology and terminology would have to be updated, this would pass for a practical preparation of mercuric oxide in an introductory twentieth-century inorganic chemistry textbook. ${ }^{8}$ To leave the entry at this, however, would be to miss the point of the exercise. For Lemery, the preparation of the red precipitate of mercury found its justification in its medical use.

It is a good Escarotick, it eats proud flesh; it is used for the laying open of Chancres mixt with burnt Alom, ãgytiacum, and the common Suppurative. Some do give it inwardly to four grains for to raise a Flux, but this is a dangerous undertaking, unless that Rectified Spirit of Wine be burnt two or three times upon it. ${ }^{9}$

Setting to one side the corpuscular explications of how certain of the reactions proceed, Lemery's Course of Chymistry was at base a recipe book for those who wanted to prepare medicines in order to treat the sick. In the posthumous eighteenth-century editions, ThÚodore Baron added a useful index allowing the reader to look up the preparations according to the disease to be treated. Such a collection of recipes is not what would be understood by 
chemistry by the beginning of the nineteenth century, and yet it is what Lemery and his contemporaries took to be the central part of the discipline. The subsequent transformation away from preparations for practical, medicinal purposes, to preparations for their own sake, or for the sake of chemistry alone, took place during the course of the eighteenth century. I would characterise this process as the growth of philosophical chemistry, as this was the term given to the independent, theory-oriented discipline that the word chemistry came to stand for by the end of the century.

\section{AN INDEPENDENT CHEMISTRY FOR THE EIGHTEENTH CENTURY.}

As I have already suggested, eighteenth-century France witnessed a blossoming of philosophical chemistry, and a widespread sentiment that the science should stand on its own. An important element in achieving this goal was the severing of chemistry from its medical as well as its alchemical associations, although the latter had already greatly declined. I will use Venel's well-known entry on chemistry in Diderot and D'Alembert's Encyclopédie (the Encyclopedia) to illustrate this point and to set the scene for the arrival of Lavoisier's new chemistry. This article has the additional advantage of allowing us to glimpse the changing nature of the audience for chemistry. Indeed, I believe that the rising social status of its audience played an important role in establishing the position of chemistry as an independent science, although I do not have the space to explore this issue in depth here.

Early on in his Encyclopedia article, Venel claimed that he wanted to dispel the common association that the public had been accustomed to make between chemistry and alchemy. He followed this up by pointing out a more widespread identification that was still being made between chemistry and pharmacy.

Others, and a lot more in number, limit the idea of Chemistry to its medicinal uses : these are they who ask of the product of an operation, what does it cure? They do not know Chemistry except through its remedies which practical Medicine owes to it, or at the very best by this route $\&$ through the hypotheses with which it has furnished the theoretical Medicine of the schools. $^{10}$ 
Asking 'what does it cure?' is to expect the second part of Lemery's entry on the red precipitate of mercury cited above, while the authors of chemistry texts in the middle of the eighteenth century were content to produce only the first part of the entry. ${ }^{11}$ Banishing the image of chemistry as a part of medicine, in particular a part of pharmacy, formed a crucial part of Venel's promotion of chemistry as an independent science on an equal footing with the prestigious mathematical sciences. Nevertheless, it should be borne in mind that by writing for the Encyclopedia, Venel was not writing primarily for a specialist audience of chemists, however that term might have been understood at the time. The idea of the work was to provide the interested, and well-off reader with a brief yet thorough synopsis of all branches of learning and human endeavour. In many ways the work was definitive of the enlightenment and of its most familiar actor, the philosophe. Indeed, it was just this kind of reader whom Venel sought to win over to the study of chemistry.

\footnotetext{
...we are going to try to present Chemistry from a point of view which might render it worthy of the interest of Philosophers [Philosophes], and to make them see that at least it might become something in their hands. ${ }^{12}$
}

If these philosophes were going to become chemists, then chemistry had to be made suitable for their elevated tastes and sensibilities. One part of this transformation required disengaging the science from its artisanal, pharmaceutical associations. According to Venel, however, this process of rendering chemistry more philosophical was already well advanced by the time he wrote the article. The history of the rise of philosophical chemistry had simultaneously been the history of its escape from medicine.

It is only since the sciences have spread out by a sort of overflowing [débordement], that philosophical Chemistry has come out from the breast of Medicine, where there are still today the greatest number of artists, the true professionals [gens du mÚtier] : the others (aside from 
the leading figures in the great chemical arts, a class which can supply only one or two Chemists for each nation) are, properly speaking, nothing other than amateurs. ${ }^{13}$

It was the amateurs, those with a passion for chemistry but who did not rely on the quotidian practice of any chemical art for their livelihood, who had led the way in establishing an independent, philosophical chemistry. Indeed, these amateurs would, during the second half of the century, remake French chemistry as a science far removed from alchemy and independent of its medical applications. This movement culminated in the new chemistry of Antoine-Laurent Lavoisier, a true amateur whose work set the tone for the way chemistry developed at the end of the century, and in doing so, cemented its new relationship with pharmacy. Although it was Fourcroy, as I will argue further on, who would take the new chemistry to the pharmacists, it was Lavoisier who defined the form of the new chemistry, both its theoretical and its disciplinary characteristics.

\section{LAVOISIER AND THE NEW CHEMISTRY.}

Lavoisier was one of very few major French chemists introduced to chemistry neither as a pharmacist's apprentice nor as a medical student. Instead, he received his professional training in law, and went on to make his fortune as a 'tax farmer'. Lavoisier's development as a chemist followed a childhood fascination for the sciences combined with long hours of study and experiment under the tutelage of various scientific fellow-travellers. ${ }^{14}$ Through the persistent and dedicated pursuit of his scientific interests he soon found himself to be a young, yet highly respected member of the Royal Academy of Sciences, joining a handful of distinguished doctors, pharmacists and mineralogists in the chemistry section. ${ }^{15}$

Naturally, Lavoisier did receive some of his chemical education from doctors and pharmacists as these formed the overwhelming majority of chemists in the generation that preceded his. ${ }^{16}$ Nevertheless, his original entry into the field was through experimental work relating to the mineralogical natural history of France. Moreover, his unusual introduction to the field is reflected in his life's work in chemistry, a corpus which would do more than anything else to establish the disciplinary separation between chemistry and pharmacy. 
From the point of view of this paper, Lavoisier's most significant contribution to chemistry was his clear vision of a systematic scientific discipline that would supersede a hitherto vague understanding of what was comprised by the term chemistry. The key text in Lavoisier's presentation of this view was his 1789 work the Traité élémentaire de chimie, présenté dans un ordre nouveau et d'après les découvertes modernes (translated into English as the Elements of Chemistry). ${ }^{17}$ Ostensibly inspired by a particular brand of empiricist philosophy, the book was intended to offer the reader a complete understanding of chemical species, starting from the simple elementary bases, passing through binary and then multiple combinations in order to give most of the known compounds. This text has established a central place for itself not just in the history of chemistry, but in the broader discipline of the history of science as well. The most readily accessible eighteenth-century chemistry text, it is truly remarkable for its clarity and for the forceful presentation of its new philosophical chemistry. Indeed, the text is more accessible to the modern student of the history of science than any chemistry book that preceded it due to two complementary factors. First, it was written in the recently reformed language developed by Lavoisier on a plan originally proposed by Guyton de Morveau. This language is close to the standard modern chemical nomenclature and thus the book is easier for a modern, chemically-informed audience to read than the texts that preceded it. ${ }^{18}$ Second, the work has been chosen to represent the chemical revolution to generations of students. It has, in tandem with the revolution it represents, achieved a canonical place in the history of science, and is one of the few primary texts from the history of chemistry that remains widely available.

It is important to recognise how the contents of the Elements of Chemistry differ from those of the traditional chemistry books of the seventeenth century. The book is divided into three parts, but they do not reflect the time-honoured tripartite division into the mineral, vegetable and animal realms. The first part opens with a treatment of the gases, unknown as distinct species fifty years earlier. Lavoisier finds particular satisfaction in describing how the Aristotelian elements of air and water have been analysed into distinct gaseous components, and complements this with his work on the role of caloric in decomposition (including fermentation of organic matter) and changes of state. The first part concludes with 
a presentation of how elementary and complex bases combine with oxygen to form acids, and in this section he moves freely from mineral through vegetable to animal bases as he moves from the simple to the complex. In the second part, Lavoisier continues to deploy his system, enumerating the outcomes of the combination of oxygen with other elements and compounds to give oxides, before moving on to the results of combinations between acids and complex bases. The third and final part treats chemical apparatus and its use.

The whole structure of Lavoisier's Elements of Chemistry is built around the author's conception of elementary analysis, taking thirty three elements as the components of all the known chemicals. As a result of this approach Lavoisier concentrates his attention in the mineral realm, as the inorganic chemicals are relatively simple and yet represent the greatest diversity of elements and their combinations. By contrast, the vegetable and animal realms do not receive extensive consideration. Lavoisier maintains that they can all be analysed to carbon, hydrogen and oxygen and that they could thus be systematically named, but he does not offer a great deal of information concerning the nature of these organic bases as chemical species. The prospect of renaming all the compounds in terms of their elementary components may seem prescient to us, but it was not any great boon to the pharmacists, the bulk of whose time was spent dealing with just such organic species. We can thus begin to see of what little practical use Lavoisier's text was to the pharmacist when compared to Lemery's work, for example. Anything not pertinent to the methodical presentation of his chemical system had no claim to be included. The place of mercury oxyd in the oxygenic system, for example, was all that Lavoisier had to say about it; he had no interest in giving anything but generalities on the preparation of the oxyds, much less details of any medical applications.

Indeed, what is too often ignored in analyses of Lavoisier's Elements of Chemistry is not what is included in the work, but rather what is left out. Lavoisier addressed some of these omissions explicitly in his introduction, and he had an excuse ready to hand. He argued that the treatise was intended as an introduction, and so needed to be limited in scope; there was simply not enough room to cover the practical side of chemistry, for example, something he admitted was very important. ${ }^{19}$ Lavoisier also used the excuse of limited space and the 
introductory nature of the work to absolve himself from the necessity of presenting a review of the history of chemistry, a standard practice for chemical authors of that time. There were, however, subjects omitted without any accompanying explanation. For Lavoisier, pharmaceutical concerns were simply not a part of chemistry any more, so their absence required no explanation. ${ }^{20}$ In fact, the text clearly favours the mineralogical tradition over the pharmaceutical, drawing attention to it in several places. In one subsection -- 'Of Metallic Bodies' (Des substances métalliques) -- Lavoisier explicitly recommended that the reader turn to alternative specialized works for more detailed information on how to obtain pure samples of these particular elements.

Metallurgy, or the docimastic art, teaches the means of separating them [the metals] from these foreign matters: and for this purpose we refer to such chemical books as treat upon these treatises. $^{21}$

There were likewise numerous treatises dealing with the preparation of compounds to be used as medicaments, but Lavoisier never referred to these. Clearly he considered metallurgy and chemistry to be closely allied, even if the explicitly practical orientation of the former placed it outside the sphere of the philosophical chemistry that he was articulating in his Elements of Chemistry. By contrast, Lavoisier simply had no place for pharmaceutical chemistry in his vision of the new systematic science, it was no longer a part of chemistry as he understood it, and did not even occupy the position of ally that metallurgy had retained. It seems likely that even the complete chemistry textbook he would no doubt have produced had the tide of French history not turned against him would have had little or nothing to say about pharmacy. In fact, in the plan of a fuller textbook that he did produce, pharmacy did not even find its way into the list of chemical arts that would be dealt with as secondary subjects. Admittedly these were only notes, but the chemical arts he enumerated were limited to mining, glass working, bleaching, saltpeter manufacture, and dyeing. ${ }^{22}$

In contrast to Venel, writing some 35 years earlier Lavoisier did not feel the need to get down in the trenches and fight for chemistry's place on the natural philosophical map. 
Nor did he need to explain what chemistry was and what it was not. He effectively transcended the disciplinary game of explicitly marking chemistry off from other sciences, and it usually escapes unnoticed that in doing this he made no mention of the position of pharmacy. Lavoisier took the chemistry that had already shifted away from the pharmaceutical tradition and removed it beyond any measure of doubt. It was left up to one of Lavoisier's disciples, Fourcroy, to try and re-establish filiation, but this time with chemistry as the dominant science and pharmacy as a subservient art.

\section{FOURCROY: BRINGING THE NEW CHEMISTRY TO PHARMACY.}

Antoine-François de Fourcroy, who himself believed that it was the discovery of the gases that had revolutionised chemistry, was quick to recognise the novelty of the late eighteenthcentury science. Furthermore, he saw quite clearly that chemistry was casting off its pharmaceutical associations. In an introductory work published in the same year as the new nomenclature, Fourcroy indicated that the old name of chemistry now referred to a newly created science.

Chemistry, whose name is very ancient, has only existed, properly speaking, for half a century. It is no longer the art of drawing juices from plants, as its name suggests. ${ }^{23}$

The doubtful etymology of the word chemistry that Fourcroy adopted in this passage served to remind his readers of the formerly intimate association between chemistry and pharmacy. Indeed, plant extracts would continue to form an important part of the pharmacist's trade even when it became an industry. Fourcroy, like Venel before him, was preparing his readers for a chemistry text that would contain no practical advice on the preparation of medicaments.

Fourcroy was one of a handful of key converts to Lavoisier's chemistry, which included Guyton de Morveau, Berthollet, Monge and Laplace. He publicly acknowledged his conversion in 1786, when he offered a new edition of his 1782 text, Leèons élémentaires sur l'histoire naturelle et la chimie (Elementary Lectures on Natural History and Chemistry), and the 1786 edition was renamed Éléments d'histoire naturelle et de chimie (Elements of Natural 
History and Chemistry) to signal that the changes were more than just cosmetic. Fourcroy became a vigorously evangelical disciple, and worked assiduously to spread Lavoisier's theory abroad. In fact, his 1792 book, Philosophie chimique ou vérités fondamentales de la chimie moderne disposées dans un nouvel ordre, (Chemical Philosophy) was one of the most widely read works on the new chemistry. ${ }^{24}$ It is rare that he receives very much historical credit for his contributions in the dissemination of the new chemistry, although given the intellectual bent of the history of chemistry, this is not altogether surprising.

While Lavoisier was executed in 1794, Fourcroy not only lived on, but enjoyed considerable success in the turbulent political world of revolutionary France. In fact, it was during the period of the French Revolution that he first turned his attention to converting the pharmacists to the new chemistry, while simultaneously apprising them of the new order that it introduced into chemistry and the chemical arts. In January of 1791 he launched a journal entitled La Médecine éclairée par les sciences physiques (Medicine Illuminated by the Physical Sciences) aimed at informing the medical community of the latest developments in the sciences. The journal's statement of purpose lists pharmacy alongside chemistry as one of the sciences to be covered, with the two distinct and yet apparently on an equal footing. Nevertheless, Fourcroy was quite explicit about how he saw the relationship between these two disciplines. Repeating his reflections of a few years earlier, he stressed not only the novelty of recent chemistry but also its rapid growth.

\footnotetext{
This science, which one may regard as absolutely new since the work of the moderns, could on its own, fill a great part of this Journal, either because of the new facts which it continually presents to those who cultivate it, or due to its applications to all the branches of the art of healing. ${ }^{25}$
}

The rise of an independent philosophical chemistry meant, however, a relative decline in the importance of pharmacy. This was made abundantly clear in the same introduction, when Fourcroy turned to a discussion of the chemical arts. 


\begin{abstract}
Thus, pharmacy will be nothing henceforth but an entirely chemical Art; the operations relating to the preparation of medicines will be entirely marked out following the precepts of Chemistry, and in this respect we can already regard it as a new Art. ${ }^{26}$
\end{abstract}

The regeneration of pharmacy announced here is a mixed blessing as far as its status is concerned. The positive reading suggests that pharmacy would undergo its own revolution due to the rise of chemistry as a separate discipline, and thus pharmacy could hope to become more prestigious through its association with the new science. Nevertheless, the new chemistry had not just taken a step away from pharmacy, it stood above it, in a position most people today would recognise; the independent science versus its dependent art. Moreover, Fourcroy fully expected that the new chemistry would entirely dictate the form of any new pharmacy. This goal of reforming pharmacy in the image of the new chemistry was to play an important role in many of Fourcroy's subsequent undertakings, including another journal he established, Journal de la Société des pharmaciens de Paris (The Journal of the Paris Society of Pharmacists), this time aimed exclusively at the community of pharmacists. ${ }^{27}$

Fourcroy did not confine himself to the propaganda efforts represented by these journals; he was also involved in the introduction of wide-ranging institutional reforms. These reforms dramatically changed the context in which pharmacy was practiced, moving it from its traditional guild structure to a state-administered regime centred on a few newlyreformed schools of pharmacy. The very possibility of Fourcroy's effectiveness in reforming pharmacy depended on his political influence under the Directory and particularly under Napoleon. His success in the turbulent world of French Revolutionary politics was remarkable; from being an ancien regime Academician, and professor of chemistry at the Jardin du Roi, Fourcroy became a deputy in the national convention, and even a member of the infamous Committee of public safety, although this only after the fall of Robespierre and the limitation of its powers. Fourcroy's political star continued to rise under Napoleon's rule, and in 1803 he realised the most sweeping reform of French pharmacy since the fifteenth century. The law of Germinal, as it was known, transferred ultimate authority over pharmacy 
from the guild to the state and instituted systematic school-based education for the elite pharmacists.

The new schools of pharmacy established by the law of Germinal provided the opportunity to educate a new generation of pharmacists in Lavoisier's chemistry, although following an approach conceived by Fourcroy. The corollary was that the schools offered another vehicle for realising Fourcroy's vision of the separation of chemistry from pharmacy which he had been proclaiming for over a decade. From now on at least the school-educated pharmacists would not make the mistake of thinking that the mundane preparation of medicaments counted as chemistry. Fourcroy's institutional reforms helped to define pharmacy at least as much as his journals and chemistry texts did, and following the approach that I have presented in this paper, the disciplinary identity of the new chemistry was shored up in the process. Despite the importance of this institutional story, it would take me beyond the brief of this paper to discuss it in detail. I want therefore to finish by returning to the textual tradition in chemistry, and in particular the revision of the Encyclopedia that symbolically affirmed the definitive disciplinary separation between chemistry and pharmacy.

\section{ENCYCLOPÉDIE MÉTHODIQUE.}

Even before it was finished, Diderot and D'Alembert's Encyclopedia was recognised by its editors as inadequate and obsolete. Diderot began planning a revised publication almost straight away and just such an expanded version of the Encyclopedia was produced under the title of the Encyclopédie méthodique, published between 1782 and 1832. This monumental project, masterminded by the printer and publisher Panckoucke, continued first by his son-inlaw and subsequently by the latter's widow, consisted of a series of independent dictionaries covering the most important fields of science and the arts. ${ }^{28}$ The updating of the Encyclopedia in the face of prodigious expansion in the world of technical learning meant that chemistry, pharmacy and metallurgy would share their own dictionary, as one of the disciplinary subsections of the Encyclopédie méthodique. Undertaken by Guyton de Morveau in the 1780's, he oversaw the production of only the first volume of this dictionary. It was midway through this volume that Guyton explained his own conversion to the new chemistry 
and subsequently wrote an extensive discussion of the acids from the point of view of the new oxygen theory. This meant that the first volume never advanced beyond 'acids'. ${ }^{29}$

Guyton de Morveau committed himself so fully to politics that he was left with no time for this encyclopedic project, and the second volume of the dictionary of chemistry, pharmacy and metallurgy was taken over by Fourcroy. As the volumes continued to appear, a subscriber might have hoped to be able to read a full description of what constituted contemporary pharmacy when the alphabetical moment arrived. Any such expectation would not, however, be fulfilled. A brief announcement at the head of volume four (1805) removed pharmacy from the purview of this dictionary. Here Fourcroy, under a thin disguise of flattery, laid bare the disciplinary transformation of pharmacy and chemistry that I have been describing in this paper.

\footnotetext{
The articles on Pharmacy have been separated from it [the dictionary]. The pharmaceutical art was thought to be interesting enough in itself to be the subject of a separate Dictionary, and also there is not, today, as formerly was the case, an intimate enough relationship, a necessary enough connection between the preparation of medicines and knowledge of general chemistry to make these two subjects inseparable. Pharmacy assuredly merits a Dictionary of its own, due to its important utility and its progress; but, being dependent on Chemistry, it is really nothing but a chemical art, one of its practical applications which does not form an essential element, as one might have thought formerly. This separation of Pharmacy gives Chemistry the space which it demands in the following volumes of this dictionary, the necessity of which the [present] state of the science has made obvious. ${ }^{30}$
}

Pharmacy had fallen victim to the expansion of an independent philosophical chemistry; the separation was complete. Formerly, texts assumed an image of chemistry that stressed the link between chemistry and the art of providing medicaments, with the latter making the former worthwhile pursuing. By the end of the eighteenth century, and particularly in Lavoisier's work, the connection was lost in the forcible promotion of a philosophical version of chemistry that had no place for pharmacy. 
While metallurgy managed to remain in the Encyclopedic dictionary of chemistry as providing the means for extracting minerals, pharmacy was finally, formally placed outside the disciplinary bounds of chemistry proper. One might be tempted to take Fourcroy at his word and regard this as a recognition of the exceptional worth of pharmacy; after all, he did claim that it deserved its own dictionary. There was, however, no volume dedicated to pharmacy. This updated version of the Encyclopedia offers the definitive signal that, at the dawn of the nineteenth century, pharmacy was no longer considered a part of chemistry. That chemistry had once been considered a part of pharmacy was by now a distant memory.

\section{CONCLUSION: A BROADER REVOLUTION.}

How does such a disciplinary approach contribute to our understanding of eighteenth-century chemistry and, more particularly, of the chemical revolution? The answer is that it helps us in several ways, all more or less interconnected. First, it provides an alternative context for a history that is standardly presented solely in terms of a succession of theories; corpuscular, phlogiston and finally oxygen. Tracing the evolving line of demarcation between pharmacy and chemistry reveals a different history; the gradual re-orientation of the science of chemistry away from its intimate connections with the preparation of medicines which had been constitutive of the seventeenth-century science. ${ }^{31}$ Thus, as I have shown in this paper, we can consider the various eighteenth-century chemists in other terms than simply their adherence to one theory or another. They also have a role to play in a developing disciplinary division. We see how in this respect Lavoisier, for example, was the culmination of a tendency towards chemistry's independence, rather than simply the inventor of a whole new science. To place him in this disciplinary context is not, however, to denigrate his scientific achievements, rather it allows us to see him as acting on a wider stage, implementing his vision of the place of chemistry in the scientific world in addition to constructing a new chemical theory. Furthermore, this approach allows us to widen our vision of who was actually involved in the chemical revolution, as the formation of a scientific discipline is an extensive enterprise that minimally involves establishing and maintaining a community of scientists. Thus we can see beyond Lavoisier to other figures such as Berthollet and Fourcroy 
who played important roles in founding the modern science of chemistry while keeping the chemical arts in their place. ${ }^{32}$

Taking discipline-formation seriously also offers the possibility of integrating the chemical revolution into a wider view of the history of science and modern European history in general. It supplies another piece in the puzzle that when completed might illuminate the regulation of an increasingly technological society as Europe entered the industrial age. ${ }^{33} \mathrm{At}$ this level, we can reconnect the chemical revolution with the social and political changes that took place in eighteenth-century France. A closer look at the institutional re-alignment of pharmacy and chemistry, for example, will reveal the vital role played by the French Revolution in establishing the form of modern chemistry. The disciplinary ideal of a rigid hierarchy of independent science and dependent art could only be fully realised in the reforming ferment of the Revolution.

Finally, one benefit of this approach that I want to stress is its drawing pharmacy squarely into the historical picture. Although widely recognised as an important scientific discipline, pharmacy has largely been ignored by mainstream history of science, which has not been able to find a place for it. I have attempted to reintroduce pharmacy as an indispensable part of the history of chemistry, and at the same time give a new perspective that might allow us better to understand pharmacy's own development during the nineteenth and twentieth centuries. 
${ }^{1}$ Thomas Kuhn, The Structure of Scientific Revolutions, 2nd ed. (Chicago: University of Chicago Press 1970). James Bryant Conant, The Overthrow of the Phlogiston Theory: The Chemical Revolution of 1775-1789, (Cambridge: Harvard University Press, 1950).

${ }^{2}$ It is important to remember that the details of the emergence of chemistry as a distinct discipline varied from country to country. I am here only dealing with France. Also, it should be borne in mind that there were other 'chemical' communities apart from pharmacy involved, such as metallurgy, distilling and dyeing, each worthy of their own studies.

${ }^{3}$ The current trends fall into two camps (i) to pinpoint the intellectual switch that can be claimed to be the chemical revolution or (ii) to understand what contemporaries took to have constituted the revolution.

${ }^{4}$ My approach, particularly in stressing the multi-facetted nature of the chemical revolution reflects that of John McEvoy . See his "The Chemical Revolution in Context." The Eighteenth Century: Theory and Interpretation. 33 (1992), 198-216.

5 Bernard Le Bovier de Fontenelle, Éloges des académiciens, 1st edn 1740, (Brussels: Culture \& Civilisation, 1969), vol. I p.340.

${ }^{6}$ This is a translation of the full French title, Cours de chymie contenant la maniere de faire les operations qui sont en usage dans la médecine, par une méthode facile avec des raissonnemens sur chaque operation, pour l'instruction de ceux qui veulent s'appliquer à cette science, while the 1677 English translation by Walter Harris was entitled A Course of Chymistry Containing the Easiest Manner of performing those Operations that are in use in Physick Illustrated with many Curious Remarks and Useful Discourses upon each Operation.

7 Nicolas Lemery, Cours de chymie, (Paris: Lemery, 1675), p. 167. The English is from Walter Harris's 1677 translation; Nicolas Lemery, A Course of Chymistry, (London: Kettilby, 1677), p.102.

${ }^{8}$ Charles Loudon Bloxam, Chemistry Inorganic and Organic with Experiments, 9 th Edn rewritten and revised by John Millar Thomson and Arthur Bloxam, (London: J. \& A. Churchill, 1903) p. 498.

9 op. cit. (7), pp.167-168.

${ }^{10}$ Gabriel-François Venel, "Chymie" in Denis Diderot \& Jean D'Alembert, Encyclopédie, vol. III, (Paris: Panckoucke, 1753) 408-437 on p. 408.

${ }^{11}$ For example, Macquer's Elements of Chemistry (1749-1751) does not feature information on medicinal doses of the chemicals discussed, although his Dictionary of Chemistry (1766) does.

12 op. cit. (10), p. 410.

13 ibid, p.431.

${ }^{14}$ Many intellectual and personal biographies of Lavoisier have been written. Recent ones, produced to coincide with the bicentennial of his death on the guillotine in 1794 include. Bensaude-Vincent, Bernadette Lavoisier: Mémoires d'une révolution. (Paris: Flammarion, 1993) (to be translated into English by Harvard University Press); Donovan, Arthur Antoine Lavoisier: Science, Administration and Revolution. (Oxford: Blackwell Publishers, 1993); Poirier, Jean-Pierre Antoine-Laurent de Lavoisier: 1743-1794. (Paris: Pygmalion, 1993). An English translation is now available: Jean-Pierre Poirier, Lavoisier: Chemist, Biologist, Economist. Trans. Rebecca Balinski. (Philadelphia: University of Pennsylvania Press, 1996).

${ }^{15}$ In 1768, Lavoisier became a supernumerary adjunct member, and the following year became an adjunct member when Jars died.

${ }^{16}$ We are told that Lavoisier attended chemistry lectures given by both Rouelle and la Planche who certainly did not leave the medical applications to one side. For his mixed reaction to Rouelle's course see Bernadette

Bensaude-Vincent "A view of the chemical revolution through contemporary textbooks: Lavoisier, Fourcroy and Chaptal" British Journal for the History of Science. 23 (1990) :435-460.

${ }^{17}$ When he translated Lavoisier's work into English, Robert Kerr gave it this title by which it has become standardly known in the English-speaking world. This is not a literal translation, as the French title was An Elementary Treatise on Chemistry.

${ }^{18}$ See Maurice Crosland Historical Studies in the Language of Chemistry.(London: Heinemann, 1962).

${ }^{19}$ See Antoine Lavoisier Elements of Chemistry, Trans. Robert Keir. \& Ed. Douglas McKie. (New York: Dover, 1965), p. xix.

${ }^{20}$ Macquer in his Dictionary of Chemistry (1766) continued to offer information on the doses of certain chemicals.

${ }^{21}$ op.cit. (19), p. 159.

${ }^{22}$ Bensaude-Vincent, Bernadette "A view of the chemical revolution through contemporary textbooks: Lavoisier, Fourcroy and Chaptal" British Journal for the History of Science. 23 (1990): 435-460. Appendix 1, p. 456. Lavoisier does, however, think that knowledge of "les drogues simples" understood as knowledge of the natural bodies as nature presents them, should form a prerequisite for the study of chemistry. (Appendix 2, p. 459). 
${ }^{23}$ Antoine-François de Fourcroy, Bibliothèque universelle des dames; principes de chimie. (Paris: Cuchet, 1787). p.x.

${ }^{24}$ See Bernadette Bensaude-Vincent op. cit. (22)

${ }^{25}$ Antoine-François de Fourcroy, La Médecine éclairée par les sciences physiques, ou Journal des découvertes relatives aux différentes parties de l'art de guérir, rédigé par M. Fourcroy Volume I (Paris: Buisson, 1791), p.18.

${ }^{26}$ ibid, pp. 32-34. .

${ }^{27}$ The full title of the journal was Journal de la société des pharmaciens de Paris ou recueil d'observations de chimie et de pharmacie, and it was published between 1797 and 1799, before merging with the Annales de chimie. For more about this journal see Susan Court and William A Smeaton. "Fourcroy and the Journal de la société des pharmaciens de Paris." Ambix 26.1 (1979): 39-55.

${ }^{28}$ For more of the intricate and intriguing publishing history of the Encyclopédie méthodique see Robert Darnton The Business of Enlightenment: A publishing History of the Encyclopedie 1775-1800 (Cambridge: Harvard University Press, 1979), chapters VIII and IX.

${ }^{29}$ Encyclopédie méthodique, chimie, pharmacie et metallurgie, la chymie par M. de Morveau, la pharmacie par M. Maret, la métallurgie par M. Duhamel, (Paris: Panckoucke; Liège, Plomteux, 1786-1815), vol I. pp. 625664. Guyton wrote this second 'avertissement' inserted just before the entry on 'air' explaining his conversion to Lavoisier's theory.

${ }^{30}$ Encyclopédie méthodique, chimie et metallurgie (Paris: Panckoucke, 1786-1815), vol. IV., p. i (Avertissement).

${ }^{31}$ I believe that this complements the work of other historians of chemistry, who point to other important aspects of eighteenth-century chemistry such as experimental practice. See Frederic Holmes Eighteenth-Century Chemistry as an Investigative Enterprise. (Berkeley: Office for History of Science and Technology, University of California at Berkeley, 1989).

${ }^{32}$ For the role of Berthollet in establishing a healthy tradition of philosophical chemistry, see Maurice Crosland, The Society of Arcueil, (Cambridge: Harvard University Press, 1967).

${ }^{33}$ An important figure in disciplinary history is of course Michel Foucault whose Discipline and Punish : the Birth of the Prison. Trans. Alan Sheridan. (New York: Pantheon Books, 1977) has inspired various investigations into discipline formation in the sciences. For example Jan Goldstein Console and Classify : the French Psychiatric Profession in the Nineteenth Century. (Cambridge: Cambridge University Press, 1987). 